\title{
The use of technology to improve health care to Saskatchewan's First Nations communities
}

\author{
I Khan ${ }^{1 *}$, N Ndubuka ${ }^{2}$, K Stewart ${ }^{3,4}$, V McKinney ${ }^{5}$ and I Mendez ${ }^{6}$
}

\begin{abstract}
Background: Saskatchewan is a province of over one million people and over $13 \%$ are Indigenous peoples, many of whom live on reserve lands. Despite continued efforts, access to health care remains a significant challenge for these Indigenous people, especially those in the North.
\end{abstract}

Objective: To address this challenge, Saskatchewan's health care providers have been incorporating the use of technology for various health services. This paper describes various ways technology has been used in First Nations communities in Saskatchewan.

Methods: Several pilot projects between First Nations leaders and health care providers, in the communities as well as in the urban setting, have taken place over the past 10 years. Information on these pilots was supplemented with literature reviews and consultations with colleagues at the Northern Inter-Tribal Health Authority, the First Nations and Inuit Health Branch (FNIHB), Health Canada and lead physicians for services to the North.

Results: Numerous technologies have shown promise in aiding the timely delivery of high quality health care. Remote Presence Robotic Technology (RPRT) is a form of telemedicine that creates the sense that a clinician is at the patient's side; enabling clinical services to be provided remotely and in real time. Increasing access to internet services and providing computer tablets to community health nurses have improved patients' access to clinical care and to vital health care information. Robotic ultrasonography has been used to provide onsite care for pre-natal patients. The provision of cell phones to HIV-positive patients has improved compliance with anti-retroviral therapy and has resulted in better clinical outcomes. The Xpert MTB/RIF (Mycobacerium tuberculosis complex / resistance to rifampicin) is an automated device that, through analysis of raw sputum samples, can identify the presence of $M$. tuberculosis with greater speed, sensitivity and specificity than the conventional acid-fast bacilli (AFB) smear. Similarly, telemedicine remote communications equipment is being used for patient care across communities. Panorama is a comprehensive, integrated public health information system designed for public health professionals and is currently being introduced in 21 communities in Saskatchewan.

Conclusion: Not only do these innovative technologies appear to improve access and enhance the quality of timely care in remote communities but they also bring comfort to patients, prevent unnecessary transportation and minimize time away from work and family. Although these technologies are not a panacea for some of the determinants of health that can affect the incidence and severity of infectious diseases in First Nations, they do appear to address some of the geographic challenges faced in providing health services in remote communities.

\author{
Affiliations \\ ${ }^{1}$ First Nations Inuit Health Branch, \\ Health Canada, Saskatchewan \\ Region, Regina, SK \\ ${ }^{2}$ Northern Inter-Tribal Health \\ Authority, Prince Albert, SK \\ ${ }^{3}$ Saskatchewan Infectious Disease \\ Care Network, Saskatoon, SK \\ ${ }^{4}$ TB Prevention and Control of \\ Saskatchewan, Saskatoon Health \\ Region, Saskatoon, SK \\ ${ }^{5}$ Northern Medical Services, \\ Saskatoon, SK \\ ${ }^{6}$ Department of Surgery, \\ University of Saskatchewan \\ and Royal University Hospital \\ Saskatoon, SK
}

Correspondence: ibrahim.khan@ hc-sc.gc.ca

Suggested citation: Khan I, Ndubuka N, Stewart K, McKinney V and Mendez I. The use of technology to improve health care to Saskatchewan's First Nations communities. Can Commun Dis Rep. 2017;43(6):120-4.

https://doi.org/10.14745/ccdr.v43i06a01

\section{Introduction}

Saskatchewan is a large province; roughly the size of France. Of the one million people who inhabit the province, over $13 \%$ are First Nations (Indigenous), more than half of whom live on reserve land (1-3). Based on 2015 data, Saskatchewan human immunodeficiency virus (HIV) rates are 47 per 100,000 for First Nations people living on south central reserves and 37 per 100,000 for those living on northern reserves (4). Similarly, tuberculosis (TB) rates, addiction trends, HIV-hepatitis C co-infection, chronic diseases (such as diabetes) and traumatic injuries in Saskatchewan First Nations people remain the highest in Canada $(2,4,5)$. In spite of continued efforts, access to primary and specialized care remains a significant challenge for First Nations people, particularly those in the North. In particular, access to timely diagnosis and procedures have been a concern for a long time in remote and isolated communities $(2,3,5)$. Difficulty in accessing health services has had the greatest impact on the most vulnerable segments of the population, including children, pregnant women and the elderly $(2,3,5)$. 
Health Canada, Northern First Nations, local physicians and health authorities across the province have been exploring innovative ways to deliver health care services in the remote northern areas $(5,6,9)$. This effort has led to innovative thinking and use of various technologies, including digital and portable diagnostic devices, in the provision of health services in these communities (4-6). The objective of this overview is to describe how technology has been applied to health services in the Northern First Nations communities in Saskatchewan.

\section{Methods}

Over the past 10 years, several successful pilot projects in northern communities in Saskatchewan have set the stage for transforming the provision of health services $(5-7,11)$. These pilots included partnering with the First Nations leaders and health care providers, in the communities as well as in the urban setting, to make linkages between on- and off-reserve services possible (6). All authors are involved in a number of these initiatives. Information on these pilot projects was supplemented with literature review and consultations with colleagues at the Northern Inter-Tribal Health Authority, First Nations and Inuit Health Branch (FNIHB), Health Canada and lead physicians for services to the northern communities $(5,6,9,11-13,15)$.

The World Health Organization has defined health technologies as the "application of organized knowledge and skills in the form of devices, medicine, vaccines, procedures and systems developed to solve a health problem and improve quality of lives" (8). Technology has been used in northern Saskatchewan to increase patient access to health care services, increase health professionals access to online resources, assess the potential for long distance diagnostic interventions and improve the care of specific conditions in remote First Nations communities $(5,6)$. For the purpose of this overview, we focused largely on digital technologies and remote and portable diagnostic devices.

\section{Results}

\section{Increased patient access to health services}

One technology that has been used to increase patient access to care is Remote Presence Robotic Technology that consists of maneuverable robots ("Rosie") and portable devices ("Doc-in-the-box") that enable face-to-face encounters between patients and health care providers despite long distances. The technology, developed in California, uses a regular Wi-Fi phone signal to establish a two-way video link $(5,6,9,11-13,15)$.

\section{Increased health professional access to online resources}

The eHealth program of FNIHB (Saskatchewan region) has been supporting the First Nations on reserve communities, and other agencies across the province, to improve connectivity to network services. The majority of the First Nations on reserve communities in Saskatchewan now have access to internet services. A group of community health nurses across Saskatchewan were provided computer tablets to enhance their ability to access online clinical, public health nursing and education tools for patients for whom they provide outreach care. Preliminary results indicate that this pilot project has enabled nurses to have quick access to various resources while using these tablets during provision of mobile/outreach care in the communities $(5,7,11)$.

\section{Assessing the potential for long distance diagnostic technology}

There is a significant gap in access to diagnostic services, especially ultrasonography, in First Nations communities. Remoteness and long travel times pose significant challenges in this regard. A pilot study conducted by Dr. Mendez in 2014 used Remote Presence Robotic Technology to assess and treat acutely ill children in Pelican Narrows in central Saskatchewan $(6,15)$. The results demonstrated that the technique was safe, clinically efficacious and cost-effective, with $63 \%$ of the acutely ill children treated in their own community. Over the past 10 years, Mendez has been a champion of the use of this remote technique and has run several successful pilots, both in northern communities of Saskatchewan and around the world $(5,6,9,11,13)$. The use of remote-presence robotics and other technologies has set the stage for transforming the provision of health services. There are now 11 medical robots and portable devices in clinical practice in Saskatchewan; more than anywhere else in Canada (9).

Infectious disease doctors in Saskatchewan are also using portable fibroscans for liver clinics on reserves (7). Mendez and many other health care providers have been partnering with First Nations leaders and health care providers, in the communities as well as in urban areas, to fill in the gaps and to link the on- and off-reserve services for First Nations patients $(5,6,9,11,12)$.

The rate of new TB cases has been very high in the northern communities $(2,7)$. In addition to the routine TB screening, a new diagnostic technology, called Xpert-MTBC/RIF (M. tuberculosis complex / resistance to rifampin) is being piloted in Northern communities in an effort to offer rapid testing for suspected TB patients (10). If the test is negative, it rules out TB quickly and prevents unnecessary isolation. If the test is positive, it can lead to early diagnosis, rapid initiation of treatment and shorter exposure time of active TB to other community members $(17,18)$.

\section{Telehealth}

Telehealth is an internet-based videoconferencing technology used by many health care providers to assess patients and to provide educational sessions and training, as well as for other purposes in various health services and programs. Currently, there are 39 First Nations communities across Saskatchewan where telehealth equipment is available for use $(7,16)$. The number of communities with service and the frequency of telehealth utilization are expected to rise in the coming years across Saskatchewan. Table 1 summarizes a range of health care goals, together with the telehealth technologies being applied to meet these goals, their application in health care and their preliminary health outcomes. 
Table 1: Technologies used to improve health services for First Nations people in Saskatchewan

\begin{tabular}{|c|c|c|c|}
\hline Goal & Technology & $\begin{array}{l}\text { Use in } \\
\text { health care }\end{array}$ & $\begin{array}{c}\text { Example of } \\
\text { Outcome }\end{array}$ \\
\hline $\begin{array}{l}\text { Increase } \\
\text { patient } \\
\text { access to } \\
\text { care }\end{array}$ & $\begin{array}{l}\text { Remote Presence } \\
\text { Robotic Technology } \\
\text { creates the sense } \\
\text { that a distant } \\
\text { clinician is at the } \\
\text { side of the patient, } \\
\text { while enabling } \\
\text { clinical services } \\
\text { to be provided } \\
\text { remotely in real } \\
\text { time. Also called } \\
\text { "Doc-in-the-box" }\end{array}$ & $\begin{array}{l}\text { Used by } \\
\text { primary care } \\
\text { doctors, } \\
\text { nurses, } \\
\text { therapists } \\
\text { and outreach } \\
\text { workers, } \\
\text { emergency } \\
\text { trauma/ } \\
\text { medicine, } \\
\text { mental health, } \\
\text { pediatricians, } \\
\text { counsellors in } \\
\text { public health/ } \\
\text { HIV clinics }\end{array}$ & $\begin{array}{l}\text { Expedited } \\
\text { HIV care and } \\
\text { triaging for } \\
\text { acute conditions, } \\
\text { patient safety } \\
\text { and comfort, } \\
\text { easy and timely } \\
\text { access to health } \\
\text { services within the } \\
\text { community }(5,6,9)\end{array}$ \\
\hline $\begin{array}{l}\text { Increase } \\
\text { access } \\
\text { to online } \\
\text { resources } \\
\text { for } \\
\text { community } \\
\text { health } \\
\text { nurses/ } \\
\text { nurse } \\
\text { managers }\end{array}$ & $\begin{array}{l}\text { Tablets used } \\
\text { during mobile } \\
\text { outreach clinics and } \\
\text { visitations }\end{array}$ & $\begin{array}{l}\text { Community } \\
\text { health } \\
\text { nursing, } \\
\text { primary care, } \\
\text { medical } \\
\text { health officer } \\
\text { and mobile } \\
\text { outreach } \\
\text { teams } \\
\text { within the } \\
\text { communities }\end{array}$ & $\begin{array}{l}\text { Easy to carry and } \\
\text { timely access to } \\
\text { online nursing/ } \\
\text { clinical/public } \\
\text { health and other } \\
\text { relevant education } \\
\text { resources, } \\
\text { improved quality } \\
\text { of care and time } \\
\text { savings (11) }\end{array}$ \\
\hline \multirow[t]{2}{*}{$\begin{array}{l}\text { Improve } \\
\text { the care } \\
\text { of specific } \\
\text { conditions }\end{array}$} & $\begin{array}{l}\text { Internet-based } \\
\text { videoconferencing- } \\
\text { like technology }\end{array}$ & $\begin{array}{l}\text { Used by many, } \\
\text { including } \\
\text { health care } \\
\text { providers, } \\
\text { to assess } \\
\text { patients, for } \\
\text { educational } \\
\text { sessions and } \\
\text { trainings and } \\
\text { for other } \\
\text { purposes in } \\
\text { health services } \\
\text { and programs }\end{array}$ & $\begin{array}{l}\text { Currently used } \\
\text { in } 39 \text { health } \\
\text { centers across } \\
\text { First Nations } \\
\text { jurisdictions. } \\
\text { Facilitated regular } \\
\text { assessment of } \\
\text { tuberculosis } \\
\text { patients, improved } \\
\text { compliance } \\
\text { with treatment, } \\
\text { increased } \\
\text { frequency } \\
\text { of follow-up } \\
\text { and improved } \\
\text { treatment } \\
\text { outcomes }(7,10, \\
11,16)\end{array}$ \\
\hline & $\begin{array}{l}\text { Cell phones for } \\
\text { HIV-positive } \\
\text { patients }\end{array}$ & $\begin{array}{l}\text { HIV and TB } \\
\text { programs } \\
\text { in the } \\
\text { communities }\end{array}$ & $\begin{array}{l}\text { Improved } \\
\text { attendance at } \\
\text { clinics, treatment } \\
\text { outcomes } \\
\text { and case } \\
\text { management, and } \\
\text { ensured regular } \\
\text { communication } \\
\text { with the patients } \\
\text { regarding follow- } \\
\text { up }(9,11)\end{array}$ \\
\hline
\end{tabular}

Table 1: Technologies used to improve health services for First Nations people in Saskatchewan (continued)

\begin{tabular}{|c|c|c|c|}
\hline Goal & Technology & $\begin{array}{c}\text { Use in } \\
\text { health care }\end{array}$ & $\begin{array}{c}\text { Example of } \\
\text { Outcome }\end{array}$ \\
\hline $\begin{array}{l}\text { Improve } \\
\text { the care } \\
\text { of specific } \\
\text { condition } \\
\text { (con't) }\end{array}$ & $\begin{array}{l}\text { Panorama is a } \\
\text { comprehensive, } \\
\text { integrated public } \\
\text { health information } \\
\text { system designed } \\
\text { for public health } \\
\text { professionals }\end{array}$ & $\begin{array}{l}\text { In } \\
\text { immunization } \\
\text { programs, it } \\
\text { expedited } \\
\text { inventory of } \\
\text { vaccines and } \\
\text { monitoring } \\
\text { in the } \\
\text { communities. } \\
\text { Operated by } \\
\text { community } \\
\text { health } \\
\text { nurses/nurse } \\
\text { managers and } \\
\text { medical health } \\
\text { officers }\end{array}$ & $\begin{array}{l}\text { The system helps } \\
\text { professionals work } \\
\text { together more } \\
\text { effectively to manage } \\
\text { vaccination programs, } \\
\text { outbreak investigations } \\
\text { and family health in } \\
21 \text { communities. More } \\
\text { communities to join in } \\
\text { the future }(7,10)\end{array}$ \\
\hline \multirow[t]{4}{*}{$\begin{array}{l}\text { Improve } \\
\text { diagnostics }\end{array}$} & $\begin{array}{l}\text { Robotic } \\
\text { ultrasonography for } \\
\text { pre-natal care }\end{array}$ & $\begin{array}{l}\text { Prenatal care } \\
\text { providers }\end{array}$ & $\begin{array}{l}\text { Improved patient } \\
\text { convenience, time, } \\
\text { travel and cost, and } \\
\text { had less impact on } \\
\text { families }\end{array}$ \\
\hline & $\begin{array}{l}\text { Remote Presence } \\
\text { Robotic Technology } \\
\text { for point of care } \\
\text { diagnosis and } \\
\text { treatment }\end{array}$ & $\begin{array}{l}\text { Primary care } \\
\text { providers and } \\
\text { specialists }\end{array}$ & $\begin{array}{l}\text { Improved patient } \\
\text { convenience, time, } \\
\text { travel and cost savings, } \\
\text { and had less impact on } \\
\text { families }(5,6,9,11-13,15)\end{array}$ \\
\hline & Portable fibroscan & $\begin{array}{l}\text { Nurses } \\
\text { specializing } \\
\text { in liver health } \\
\text { and doctors } \\
\text { specializing } \\
\text { in infectious } \\
\text { diseases }\end{array}$ & $\begin{array}{l}\text { Used for assessment } \\
\text { and staging of liver } \\
\text { fibrosis in patients with } \\
\text { hepatitis B and C (7). } \\
\text { Assessment provided } \\
\text { within the communities }\end{array}$ \\
\hline & $\begin{array}{l}\text { Xpert MTB/RIF is a } \\
\text { new molecular test } \\
\text { for tuberculosis and } \\
\text { other conditions }\end{array}$ & $\begin{array}{l}\text { Rapid TB } \\
\text { diagnostics }\end{array}$ & $\begin{array}{l}\text { Timely diagnosis of TB } \\
\text { and early prevention } \\
\text { of possible exposure, } \\
\text { recently Installed in } \\
\text { northern communities } \\
\text { to support TB high } \\
\text { incidence strategy } \\
(10,17,18)\end{array}$ \\
\hline
\end{tabular}

Abbreviations: HIV, human immunodeficiency virus; MTB/RIF, Mycobacterium tuberculosis/ rifampicin; TB, tuberculosis

\section{Discussion}

The success of the use of robotic technology, internet, tablets, cell phones with disease-specific applications, telehealth, remote ultrasound and liver scans, as well as integrated electronic public health information systems and rapid diagnostic testing, have demonstrated that electronic/digital technologies can improve access to health services for remote First Nations communities. The use of technology has improved access of professionals to timely health care information, and has the potential to improve diagnostics capacity in the neediest areas of Saskatchewan. It has already enhanced timely client care and access to a wide variety of medical expertise in remote northern communities. These technologies have also increased the uptake of treatment and preventative measures such as vaccination and increased access to critical services $(5,6,9,11,12,15,16)$. Technology use in health services have also proven to be cost-effective $(2,5,6,9,16)$. 
The increased use of health care technologies in remote northern communities in Saskatchewan has been positively received by patients. These technologies have resulted in increased patient comfort, as they avoid unnecessary transportation, and mean that people can stay with their families in their communities. In addition, through the use of these technologies, people have been empowered to help take care of their own health.

Although these technologies have helped to fill some of the existing gaps in the primary care to First Nations jurisdictions, there are some limitations that need to be considered: the use of technology can never completely replace the benefits of a direct or in-person encounter between a patient and a health care provider (14); technology can be resource intensive; and it requires training $(11,16)$. To integrate the use of technology requires time and effort, and this integration involves extensive consultations with First Nations communities, local health care providers and First Nations leadership, as well as with representatives from various levels of government $(5,6,11,16)$. Finally, technologies are not a panacea for some of the determinants of health that can affect the incidence and severity of infectious diseases in First Nations communities; however, their use does appear to address some of the geographic challenges that must be faced in providing health services to remote communities.

Because these are only preliminary findings, a formal and systematic evaluation of current practices would be of great value for future expansion of the use of these technologies. It would also be worthwhile to explore how these practices, and the lessons learned from these pilot projects, can be used in other areas to fill the gaps in services and improve health outcomes in the long term.

\section{Conclusion}

Currently, an increasing numbers of physicians and other health care professionals across Saskatchewan are using innovative technologies to improve access to health services. While gaps still exist, and more research is needed, the use of these technologies appears to be a safe, effective and cost-effective way to improve health care to remote First Nations and other communities.

\section{Authors' statement}

IK - conceptualization, investigation, writing original draft, methodology, software, validation, review and editing; KS, ND, VM - knowledge-sharing, review and editing

\section{Conflict of interest}

IK, NN, VM and IM have no conflict of interest to declare.

KS is a consultant and adviser to Gilead Sciences, AbbVie, Merck and has received grants from Gilead, AbbVie, Merck, Roche, Vertex Pharmaceuticals and ViiV Healthcare, but has no investments in any companies involved in pharmaceuticals or health care.

\section{Acknowledgements}

Our profound thanks to Drs. Katherine Hennessy and Normen Ducharme at Health Canada for their support, expertise and contributions to this manuscript and for their incredible work in the area. Their ongoing commitment to the health of northern communities is deeply appreciated.

\section{Funding}

None.

\section{References}

1. Bureau of Statistics, Government of Saskatchewan. Available from: http://www.stats.gov.sk.ca/.

2. Health Canada. First Nations Health Status Report, 2012 [Internet]. Available from: http://publications.gc.ca/ collections/collection_2015/sc-hc/H34-293-2015-eng.pdf.

3. Statistics Canada. Janine C. Health at a Glance, Difficulty accessing health care services in Canada [Internet], Dec 8th 2016. Available from: http://www.statcan.gc.ca/ pub/82-624-x/2016001/article/14683-eng.htm.

4. Charlton J. Saskatoon StarPhoenix, Sask First Nations could turn corner on HIV by 2020 [Internet]. Available from: http://thestarphoenix.com/health/sexual-health/sask-firs t-nations-could-turn-corner-on-hiv-by-2020.

5. Dr. Mendez. CTV News Saskatchewan interview. 'Doctor in a box' soon to be used in clinical trails; November 23, 2013. Available from: http://saskatoon.ctvnews.ca/doctor-in-a-bo x-soon-to-be-used-in-clinical-trials-1.1557674.

6. Government of Saskatchewan [Internet]. Pioneering Robotics Technology Benefits Patients in the North, Sept 2016. Available from: https://www.saskatchewan.ca/government/ news-and-media/2016/september/27/robot.

7. Khan I, First Nations Inuit Health-Health Branch, Health Canada eHealth program communication 2017, Saskatchewan Region.

8. World Health Organization. Health Technology Assessment [Internet]. Available from: http://www.who.int/medical_ devices/assessment/en/.

9. Ellen B. Five ways robots are delivering health care in Saskatchewan [Internet]. CBC News Saskatchewan, Feb 2015. Available from: http://www.cbc.ca/news/canada/saskat chewan/5-ways-robots-are-delivering-health-care-in-saskatch ewan-1.2966190.

10. Khan I, Ndubuka N. 2017 TB program communication. Health Canada. 2017.

11. Mendez I, Van den Hof M. Mobile remote-presence devices for point-of-care health care delivery. CMAJ. 2013;185(17):1512-6. DOI: http://dx.doi.org/10.1503/ cmaj.120223. PubMed (https://www.ncbi.nlm.nih.gov/ pubmed/23775612?dopt=Abstract).

12. Mendez I, Jong M, Keays-White D, Turner G. The use of remote presence for health care delivery in a northern 
Inuit community: a feasibility study. International Journal of Circumpolar Health. 2013;72(1):10. DOI: http://dx.doi. org/10.3402/ijch.v72i0.21112. PubMed (https://www.ncbi. nlm.nih.gov/pubmed/23984292?dopt=Abstract).

13. Lovo Grona S, Bath B, Bustamante L, Mendez I. Using a remote presence robot to improve access to physical therapy for people with chronic back disorders in an underserved community. Physiotherapy Canada. 2017;69(1):14-9. DOI: http://dx.doi.org/10.3138/ptc.2015-77 PubMed (https:// www.ncbi.nlm.nih.gov/pubmed/28154440?dopt=Abstract).

14. Buckeridge D. 2016 plenary session at 2016 CPHA conference [Internet]. 2016. Available from: http://www.cpha. ca/en/conferences/archives/conf2016/plenaries.aspx.

15. Adams $S$, Burbridge B, Badea, A, Langford L, Vergara $V$, Bryce R, Bustamante L, Mendez I, Babyn P. Initial Experience Using a Telerobotic Ultrasound System to Perform Adult Abdominal Examinations. Canadian Association of Radiologists Journal. 2016. DOI: http://dx.doi.org/10.1016/j. carj.2016.08.002.
16. Abdullah $\mathrm{N}$, Nancy $\mathrm{C}$. Telehealth in rural Canada, medicine and technology [Internet]. UWOMJ 2014;83(1):49-50. Available from: http://www.uwomj.com/wp-content/ uploads/2014/10/v82no1_16.pdf.

17. Luetkemeyer AF, Firnhaber C, Kendall MA et al. Evaluation of Xpert MTB/RIF Versus AFB Smear and Culture to Identify Pulmonary Tuberculosis in Patients with Suspected Tuberculosis From Low and Higher Prevalence Settings. Clin Infect Dis. 2016;62(9):1081-8. DOI: http://dx.doi. org/10.1093/cid/ciw035. PubMed (https://www.ncbi.nlm.nih. gov/pubmed/26839383?dopt=Abstract).

18. Oxlade O, Sugarman J, Alvarez GG. Xpert® MTB/RIF for the Diagnosis of Tuberculosis in a Remote Arctic Setting: Impact on Cost and Time to Treatment Initiation. PLoS One. 2016 Mar 18;11(3):e0150119. DOI: http://dx.doi.org/10.1371/ journal.pone.0150119. PubMed (https://www.ncbi.nlm.nih. gov/pubmed/26990299?dopt=Abstract).

\section{Canadian Guidelines on Sexually Transmitted Infections}

\section{Mobile App Updated-May 2017!}
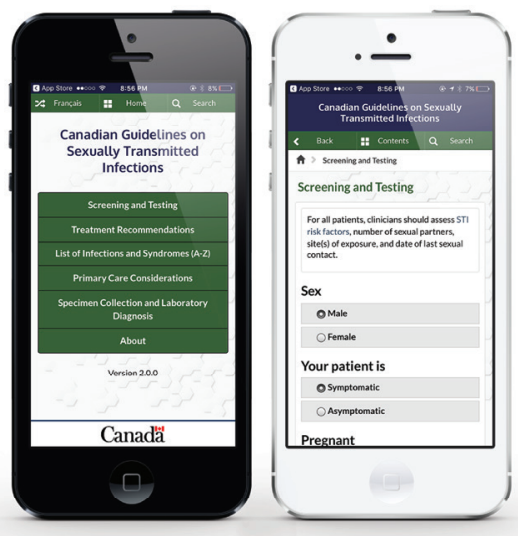

What's New in Version 2.0.0

- Updated content

- Improved interactivity

- General bug fixes and performance improvements

$\begin{array}{ll}\text { Public Health } & \text { Agence de la santé } \\ \text { Agency of Canada } & \text { publique du Canada }\end{array}$ 